\title{
La responsabilidad patrimonial de los concesionarios de obras públicas por los daños sufridos por terceros durante la fase de explotación de la concesión
}

\section{Liability of concessionaires for damages suffered by third parties during concession's operational phase}

Martín Loo Gutiérrez

El trabajo presenta el estado actual del derecho que regula la responsabilidad de los concesionarios frente a terceros que sufren daños en las obras públicas concesionadas durante su fase de explotación. Al respecto es posible advertir que la jurisprudencia de nuestras Cortes ha elaborado, al menos, dos soluciones que siguen caminos argumentativos diversos. Se someterá a juicio crítico ambas respuestas y se concluirá que la responsabilidad de los con cesionarios por los daños sufridos por terceros, tengan o no la calidad de usuarios, durante la fase de explotación de la concesión, es de naturaleza extracontractual y, por tanto, no se en-
This paper depicts the current status of the law regulating the liability of concessionaires for third party damages during the operating stage of public works concessions. In this regard, Chilean case law has provided at least two solutions, with a different line of argument. Both workarounds shall be subject to critical scrutiny, to finally conclude that concessionaires, during the operating phase of a concession, are liable in tort rather than contract for third party damages, and are thus not subject to the provisions of the Consumer Protection Law.

\footnotetext{
* Profesor de Derecho Administrativo, Pontificia Universidad Católica de Valparaíso. Doctor en derecho por la II Universidad de Roma Tor Vergata. Correo electrónico: martin.loo@ pucv.cl. Correo postal: Av. Brasil 2950, Valparaíso, Chile.

Este trabajo fue financiado por Conicyt (hoy ANID) a través del proyecto Fondecyt Regular No 1180608 (Prof. Ínigo de la Maza Gazmuri, investigador responsable). Agradezco las observaciones de los pares evaluadores a una versión preliminar de este trabajo. Agradezco especialmente al ayudante del departamento de derecho público de la PUCV, señor Juan Ignacio Johnson Narváez, por la valiosa colaboración prestada en la investigación jurisprudencial.
}

Artículo recibido el 17 de marzo de 2021 y aceptado el 6 de junio de 2021. 
cuentra sujeta a las normas de la Ley de Protección del Consumidor.

Palabras clave: responsabilidad civil contractual, responsabilidad civil extracontractual, concesión de obras públicas, ley del consumidor, daños a usuarios.
Keywords: civil liability by breach of contract, tort law, public works concessions, consumer law, tort damages.

\section{Introducción}

El contrato de concesión de obra pública genera un conjunto de relaciones jurídicas entre el Estado, el concesionario y los usuarios de las obras y servicios concesionados, todas las cuales se encuentran sometidas a un régimen jurídico, más o menos, especial. Este trabajo aborda las relaciones que se generan con ocasión de los accidentes sufridos por los usuarios durante el período de explotación de la concesión y sostiene que su régimen es el de la responsabilidad civil extracontractual, descartando con ello la posible aplicación de la Ley N 19.496, sobre Protección de los Derechos de los Consumidores (LPC).

Para afirmar lo anterior es preciso tener en cuenta que, en virtud de este contrato administrativo, el Estado encarga a un particular la prestación de un servicio público para cuya realización es necesaria la construcción o rehabilitación de una obra pública que, luego, será explotada para obtener los ingresos destinados a solventar los costos de construcción, de mantenimiento y para generar una utilidad económica. Dicha explotación corresponde a la prestación de un servicio público cuyo beneficiario inmediato puede ser la población general (como sucede, por ejemplo, en las autopistas y aeropuertos), o bien, la misma Administración Pública (como ocurre en los hospitales y en los centros de cumplimiento penitenciario). Sin perjuicio de quién sea el receptor directo de los servicios públicos que desarrolla el concesionario, como se ha indicado en otro lugar ${ }^{1}$ el contrato de concesión de obra pública corresponde a una forma de ejecución de obras públicas caracterizada por la manera en la que la Administración remunera al contratista, la cual puede adoptar dos modalidades. En primer lugar, dicha remuneración puede derivar de la concesión de la explotación comercial de la infraestructura, esto es, en la autorización que se confiere al concesionario para recaudar una suma de dinero de los usuarios de la obra realizada; suma que es establecida en el contrato de concesión. En segundo lugar, la remuneración del concesionario puede provenir de pagos realizados directamente por la Administración concedente; pagos que nuestra legislación denomina subsidios².

La primera es la modalidad más elemental y describe bien la funcionalidad básica de este contrato: la empresa privada adjudicataria del contrato

\footnotetext{
Loo 2019b, 332-333.

2 Véase, además, Moraga 2019, 187.
} 
se obliga a recaudar el financiamiento, a construir, a mantener y a explotar una obra pública a cambio de lo cual la Administración Pública la autoriza a cobrar, en su nombre, pero en beneficio propio, una suma de dinero a quienes utilicen la obra realizada. El conjunto de dichos pagos, por un período extenso de tiempo (que, de acuerdo con el art. 25 de la Ley de Concesiones de Obras Públicas ${ }^{3}$ puede llegar hasta los cincuenta años), constituirá la remuneración del contratista.

La segunda modalidad de remuneración consiste en pagos realizados por la Administración concedente. Existen esquemas contractuales en los cuales el Estado es quien paga directamente al concesionario sobre la base de la disponibilidad u otros parámetros funcionales o de utilización de la infraestructura (por ejemplo, determinadas por su demanda de uso). La legislación chilena reconoce esta forma o modalidad del contrato de concesión en el artículo 11 LCOP, al prescribir que "el concesionario percibirá como única compensación por los ser vicios que preste, el precio, tarifa o subsidio convenidos y los otros beneficios adicionales expresamente estipulados" 4 .

Cualquiera sea la modalidad en la cual se convenga el contrato de concesión resulta claro que crea una relación jurídica de naturaleza contractual entre el Estado concedente -en nuestro ordenamiento, a través de la Dirección General de Concesiones de Obras Públicas del Ministerio de Obras Públicas- y la sociedad concesionaria. En otras palabras, en virtud del contrato de concesión de obra pública surge una relación jurídica de derecho público entre el Estado y el concesionario, sometida a la regulación típica de los contratos administrativos. Esto significa que, cualquiera sea la modalidad del contrato de concesión, es siempre el Estado quien remunera la actividad desarrollada por el concesionario, sea a través de la autorización para recaudar tarifas (peajes, derechos de embarque, etc.), sea a través de aquellos pagos directamente realizados por la Administración que nuestra legislación denomina 'subsidios's.

Otro aspecto relevante de este contrato para el presente trabajo es que se encuentra estructurado en dos fases, cada una sujeta a una específica regulación. En un primer momento, se encuentra la denominada 'fase de cons-

\footnotetext{
3 Decreto Supremo del Ministerio de Obras Públicas N 900 de 1996, que fija el texto refundido, coordinado y sistematizado del DFL N 164, de 1991, Ley de concesiones de obras públicas; en adelante, "LCOP".

4 En el derecho extranjero se conocen experiencias de contratos de concesión que utilizan esta forma de remuneración a través de subsidios estatales, incluso, para ciertas infraestructuras que, en nuestro país, se financian siempre a través de la recaudación de pagos de los usuarios. Por este motivo, en otro lugar, se afirmó que esta modalidad de la concesión de obra pública, esto es, la concesión en la cual es el Estado quien remunera al concesionario a través de subsidios, es lo que -en el extranjero- se denomina 'asociación público-privada': Loo 2019b, 355; Loo 2019a, 189.

5 Cabe apuntar que hay autores que disputan la naturaleza convencional de las relaciones entre el Estado y sus contratistas. Véase ArANCIBIA 2019b y, en contra, Loo 2018. Así mismo, en ArANCIBIA 2019a, 358 el autor califica las concesiones de obras como una "contraprestación por el cumplimento de una carga pública voluntaria que constituye el objeto principal de un acto administrativo de gravamen".
} 
trucción' de la obra pública, durante la cual el concesionario ejecuta las obras convenidas (por ejemplo, la rehabilitación y ampliación de una carretera; la construcción de un nuevo hospital; el reacondicionamiento de un centro penitenciario, etc.). Una vez que la ejecución de las obras ha culminado y la Administración ha autorizado la puesta en servicio de las mismas (art. 17 LCOP), se iniciará la fase temporalmente más extensa del contrato, denominada 'etapa de explotación', durante la cual el concesionario deberá prestar el servicio público para el cual haya sido ejecutada la obra, percibiendo las prestaciones económicas convenidas de acuerdo al tipo de infraestructura realizada. Como puede advertirse, el hecho que el concesionario recaude su compensación de parte del público o sea directamente remunerado por el Estado no modifica la naturaleza de la relación (se trata siempre de un contrato celebrado entre el Estado y el concesionario) ni tampoco altera el cuadro normativo de referencia. Tal es así que el derecho a percibir los pagos de los usuarios es un derecho derivado del contrato de concesión y no, en cambio, de alguna relación jurídica que se pueda instaurar entre el concesionario y los usuarios ${ }^{6}$.

Una segunda cuestión que conviene destacar es que, durante la fase de explotación de la obra, tal como eficazmente sostiene la doctrina, la Administración delega en el concesionario una actividad (una misión, dice $V_{a l d i v i a}{ }^{7}$, siguiendo a la doctrina francesa) que le es propia. Esta delegación de funciones estatales, como se verá más adelante, se realiza en términos particularmente amplios, de suerte que la incidencia de la Administración en la gestión cotidiana del servicio es limitada, disponiendo el concesionario de un importante margen de discreción para adoptar las decisiones necesarias para la buena marcha del servicio público cuya ejecución se le ha delegado. La Administración concedente se limitará a velar porque las condiciones en las cuales se desarrollan las prestaciones del concesionario satisfagan los términos legales y contractuales. Por ello, en la fase de explotación, el concesionario goza de una amplia libertad de gestión pese a tratarse de una actividad expresamente calificada como un servicio público ${ }^{8}$.

Entonces, como ya se señaló, la concesión de obras públicas se estructura en dos fases sucesivas específicamente reguladas por la LCOP y su

\footnotetext{
${ }^{6}$ Al efecto, puede consultarse el tenor de los distintos decretos de adjudicación de concesiones de obras públicas, especialmente, en lo relativo a los 'derechos del concesionario'. Como ejemplo puede citarse el art. 11 del decreto supremo MOP No 1205, de 17 de agosto de 2001, que adjudicó el contrato de concesión para la ejecución, conservación y explotación de la obra pública fiscal denominada 'Variante Melipilla', titulado 'derechos del concesionario', el cual dispone que este tiene derecho a 'cobrar las tarifas a todos los usuarios de la concesión...'.

7 VALDIVIA 2018, 30.

8 El artículo $61 \mathrm{~N}^{\circ} 1$ del Reglamento de la LCOP, decreto supremo del Ministerio de Obras Públicas N 956 de 1997, establece que "la obra entregada en concesión es un servicio público", lo cual da claramente cuenta de la naturaleza de la misión que desarrolla el concesionario por cuenta de la Administración: es una tarea pública prestada, orgánicamente, por una sociedad privada. Hay que reconocer, sin embargo, que existen autores que critican la atribución del carácter de servicio público a una actividad económica por medio de la potestad reglamentaria. Véase, BERMÚDEZ 2019, passim.
} 
reglamento. En este artículo se mirará la fase de explotación ya que es con ocasión de ella que la ley impone al concesionario la prestación del servicio público en condiciones de normalidad y continuidad (artículo 23 LCOP). Por su lado, el Reglamento de la LCOP, disciplina en forma detallada, en sus artículos 54 y siguientes, el régimen jurídico a que se encuentra sometido el concesionario durante esta fase de la concesión, estableciendo en el art. 62 el deber de la sociedad concesionaria de adoptar todas las medidas necesarias para evitar daños a terceros.

Del conjunto de estas normas es posible concluir que el concesionario debe observar una disciplina normativa especialísima que le impone el cumplimiento de un servicio público (artículo $61 \mathrm{~N}^{\circ} 1$ del Reglamento de la LCOP) con estándares de normalidad y continuidad (art. 23 LCOP), adoptando todas las medidas necesarias para evitar daños a terceros (art. 62 RLCOP). Daños que, de verificarse, generan responsabilidad en el concesionario "a menos que sean exclusivamente imputables a medidas impuestas por el Ministerio de Obras Públicas, después de haber sido adjudicado el contrato" (art. 35 LCOP).

La correcta inteligencia de estas normas ha dado lugar al problema que se debe enfrentar en este artículo, esto es, la determinación de la naturaleza jurídica de la responsabilidad del concesionario por los daños sufridos por terceros, sea que estos tengan, o no, la calidad de usuarios de las obras explotadas por el contratista.

De esta hipótesis surgen, al menos, las siguientes preguntas: ¿se trata de una responsabilidad de tipo contractual o extracontractual? En caso de considerarse una hipótesis de responsabilidad contractual, ¿cabe considerar a los usuarios de las obras como consumidores y, por ello, extender la protección que confiere la LPC a los adquirentes de un servicio? En caso de estimarse que se trata de una hipótesis de responsabilidad extracontractual, ¿cuál es la posición del Estado concedente frente a las responsabilidades derivadas de daños causados a usuarios de obras concesionadas?.

El desafío que este trabajo se plantea es encontrar una respuesta que unifique el régimen de responsabilidad del concesionario frente a los terceros que sufren accidentes en las obras concesionadas durante su fase de explotación. Ello es necesario porque se ha llegado al punto que, alguna decisión judicial ${ }^{9}$, ha hecho depender dicho régimen de la circunstancia que el usuario haya efectivamente pagado la tarifa de uso. Pretendo discutir esta conclusión, puesto que privilegia una respuesta que distorsiona la naturaleza del pago efectuado por los usuarios, elevándolo a la categoría de prestación contractual inter privatos. Por otro lado, esta solución es también insuficiente toda vez que no se hace cargo de los accidentes que puedan ocurrir a terceros usuarios que no deben pagar por los servicios desarrollados por los concesionarios (como el peatón que atraviesa una pasarela sobre una autopista,

${ }_{9}$ Corte de Apelaciones Valparaíso Rol 641-2015, cons. $7^{\circ}$. 
el acompañante de un pasajero del aeropuerto o el interno de un centro de cumplimiento penitenciario). En estos casos, la respuesta de la responsabilidad por incumplimiento contractual del concesionario sería improcedente $y$, por ello, insatisfactoria.

Para abordar estas preguntas resulta imprescindible estudiar el estado de la jurisprudencia, la cual se encuentra dividida en dos tendencias mayoritarias: una considera que el pago de la tarifa de uso por el usuario importa la celebración de un contrato que, además, se encuentra dentro del ámbito regulatorio de la LPC; otra, estima que no existe relación contractual alguna entre usuario y concesionario y, por ende, que la responsabilidad sería de naturaleza aquiliana, considerando que el precio pagado por los usuarios es una prestación de índole tributaria o, en todo caso, de naturaleza no contractual.

En efecto, un número relevante de decisiones -provenientes, principalmente, de distintas Cortes de Apelaciones del país- considera que la responsabilidad del concesionario por los daños sufridos durante el uso de obras concesionadas (especialmente, de autopistas) se encuentra sometida a la disciplina establecida por la LPC considerando -erradamente, según mi opinión- que entre el concesionario y el usuario se instaura una relación jurídica contractual de consumo. Esta posición fue aceptada por la Corte Suprema en alguna ocasión ${ }^{10}$.

En cambio, la jurisprudencia que se ha abierto paso también en las Cortes de Apelaciones y consolidado en la Corte Suprema sostiene que el estatuto aplicable a la hipótesis es aquel de la responsabilidad extracontractual, ex artículos 2314 y siguientes del Código Civil ${ }^{11}$. Por las razones que analizaré en este artículo, considero que esta es la solución armónica tanto con la naturaleza de la relación jurídica concesional (la cual, como se dijo, corresponde a un contrato entre el Estado y el concesionario), como con el rol que la legislación le atribuye al concesionario (esto es, la condición de prestador de servicios públicos). Por otra parte, esta respuesta, según mi opinión, permite unificar el estatuto de responsabilidad de los concesionarios prescindiendo tanto del tipo de obra de la cual sean gestores (se cobre, o no, por su uso al público), como de la condición del tercero que sufre los daños (pagador de tarifa, o no), lo que permite construir un sistema de protección unitario y con reglas homogéneas a favor de las víctimas de estos. Esta respuesta, sin embargo, presenta un flanco dudoso, cual es, la posible responsabilidad patrimonial en que pueda incurrir el Estado como titular último de estas infraestructuras y servicios públicos ${ }^{12}$.

\footnotetext{
10 Corte Suprema Rol No 6370-2009.

11 Véase por ejemplo: Corte Suprema Rol No6229-2010; Rol No 216-2011; Rol № 2911-2011; Rol No 4292-2012; Rol No 5678-2012; Rol № 27.950-2014; Rol No 10.649-2015; Rol No 16.684-2018.

12 Como se sostuvo por alguna temprana doctrina, el Estado no podría desligarse y 'privatizar' la responsabilidad que le incumbe por los daños sufridos en las infraestructuras de las cuales es titular (VIÑUela 2001, passim; ViñUelA 2003, passim). No obstante, creo que esta posición se encuentra superada, como se dirá más adelante.
} 
En consecuencia, el objetivo principal de este artículo es demostrar que la responsabilidad de los concesionarios de obras públicas por los daños sufridos por terceros usuarios, a título gratuito u oneroso, durante la fase de explotación de las mismas, es una responsabilidad de naturaleza extracontractual y se encuentra regida por las disposiciones del título XXXV del Código Civil. Junto con demostrar lo anterior, se deberá cuándo el Estado concedente puede incurrir en responsabilidad patrimonial por falta de servicio ex art. 42 LOCBGAE.

Para alcanzar este objetivo se procederá a estudiar el estado actual de la jurisprudencia y la doctrina en la materia (I), para luego analizar aquellos fallos que reafirman la hipótesis de este trabajo, esto es, que esta responsabilidad es de naturaleza extracontractual, aportando, además, algunas reflexiones adicionales que refuerzan y amplían a otros supuestos de hecho la tesis acerca de la corrección de esta línea jurisprudencial (II). Deberá, asimismo, controvertirse la conclusión de que, en las hipótesis de hecho señaladas, el Estado vea en todo caso compro metida su responsabilidad por falta de servicio, situación que se presenta solo en situaciones muy restringidas, tal como correctamente ha interpretado la jurisprudencia (III). El trabajo finalizará con algunas conclusiones.

\section{El estado de la cuestión a nivel doctrinal y jurisprudencial}

Como ya se señaló, el debate jurisprudencial y doctrinal en materia de responsabilidad del concesionario por los accidentes que sufren los usuarios de las obras durante la fase de explotación se encuentra claramente dividido en dos tendencias.

La primera de ellas sostiene que dicha responsabilidad es de naturaleza contractual. Se predica esta calidad toda vez que se identifica la existencia de un contrato entre el concesionario y el usuario de la infraestructura; contrato que un número importante de los fallos consultados reconduce a la categoría de acto de consumo y respecto del cual, se aplica, por ende, el estatuto protector de la LPC. En algún caso aislado, sin embargo, se ha establecido que esta responsabilidad es contractual, pero que se encuentra sometida a la regulación de derecho común ${ }^{13}$. Como ya se dijo, esta postura gozó de amplio consenso, especialmente, a nivel de las Cortes de Apelaciones y, en alguna ocasión, de la Corte Suprema ${ }^{14}$.

La segunda postura asevera que la responsabilidad del concesionario por los daños sufridos por los usuarios es de naturaleza extracontractual, toda vez que, entre concesionario y usuario, no se concluye contrato alguno como consecuencia del pago de la tarifa de uso de la infraestructura. Esta posición es la que se ha consolidado en la jurisprudencia de la Corte Suprema y, como se verá en el apartado II, me parece acertada.

${ }_{13}$ Corte de Apelaciones Santiago Rol No 8-2017.

14 En la ya citada Corte Suprema Rol No 6370-2009. 
Esta incertidumbre jurisprudencial se encuentra bien documentada por la doctrina nacional. En el artículo más relevante para la materia objeto de este trabajo, Diez ${ }^{15}$-luego de pasar en detallada reseña las hipótesis de hecho más comunes que se ventilan ante los tribunales del país y de las cuales derivan condenas de responsabilidad respecto del concesionario de obras viales- constata que la jurisprudencia chilena, cuando entiende infringida la 'obligación de seguridad' de los concesionarios, les condena al resarcimiento de perjuicios invocando, en modo indistinto, el régimen de responsabilidad extracontractual de derecho común, el régimen de responsabilidad contractual, sea de derecho común, sea por infracción a la Ley del Consumidor, dándose por establecida -según sea la sede en la cual la víctima busque el resarcimiento, esto es, ante los juzgados civiles ordinarios o los juzgados de policía local-, la culpa aquiliana, la culpa contractual e, incluso, la falta de servicio. Ante ello, concluye el autor, se ha verificado un "acercamiento entre estos diversos regímenes a la hora de solucionar casos prácticos en esta materia"16.

Esta heterogeneidad de soluciones no puede ser satisfactoria ya que la naturaleza de la responsabilidad en que incurra el concesionario no puede depender de la sede en la cual ella se deba establecer ni del régimen jurídico que el actor decida invocar.

Por ello es necesario someter a análisis crítico las tendencias jurisprudenciales en la materia y, para ello, se pondrá especial atención a los fallos dictados con posterioridad al año 2012, fecha de publicación del estudio del Prof. Diez.

\section{La responsabilidad del concesionario como responsabilidad civil contractual}

Como ya se dijo, la primera postura que ha tomado cuerpo en nuestra jurisprudencia señala que la responsabilidad civil del concesionario por los daños sufridos por los usuarios de una obra concesionada durante la fase de explotación es de naturaleza contractual, esto es, deriva del incumplimiento de la obligación de seguridad que nace del contrato que surgiría entre el concesionario y el usuario como consecuencia del pago de la tarifa de uso de la infraestructura.

Como bien reseña Diez ${ }^{17}$ :

esta tendencia postula que entre el usuario y la sociedad concesionaria 'existe un vínculo contractual derivado del contrato de adhesión que celebra el usuario al momento de pagar el peaje', el cual le impone a aquélla, entre otras obligaciones, las señaladas en el anotado artículo 23 de la Ley de Concesiones de Obras Públicas (Decreto Nº 900 MOP de 1996).

15 DIEZ 2012, 154.

16 Ibíd., 155.

17 DIEZ 2007, 85-87. 
La jurisprudencia identifica la celebración de un contrato bilateral y oneroso entre el concesionario y el usuario puesto que aquel ofrece un servicio y este lo adquiere por medio del pago de un precio o tarifa ${ }^{18}$. Una variante de esta opinión, tomando en cuenta el carácter comercial de la actividad desarrollada por la sociedad concesionaria, al tiempo que la calidad de usuario final de quienes utilizan sus servicios, asevera que esta relación jurídica cae dentro del ámbito regulativo de la LPC ${ }^{19}$.

Es posible identificar numerosos pronunciamientos judiciales que, reconociendo la competencia de los jueces de policía local para conocer las querellas infraccionales y demandas resarcitorias deducidas por las víctimas de estos daños, han debido pronunciarse sobre la aplicación de la LPC a esta hipótesis, calificando explícitamente la relación que se instaura entre el concesionario y el usuario de la obra como una relación de consumo.

Esta opinión jurisprudencial privilegia la aplicación de los artículos 3, letra d) y 23, LPC, por sobre el art. 35 LCOP. Este razonamiento se encuentra igualmente explicado por $\operatorname{Diez}^{20}$, quien señala que:

esta tendencia también parte de la base que entre el usuario y la sociedad concesionaria existiría un 'contrato oneroso de peaje celebrado en forma particular', pero añade que en virtud de dicho contrato la concesionaria adquirió 'obligaciones cuyo cumplimiento se enmarca en la Ley $N^{\circ}$ 19.496, sobre los derechos de los consumidores', otorgándose así 'a la consumidora, quien pagó una tarifa por usar la ruta concesionada, el derecho de obtener como contraprestación: la seguridad de que la vía esté libre de peligro y obstáculos y de que se pueda circular en ella, con toda normalidad y sin riesgo de sufrir accidentes, que se pudieren haber evitado si el proveedor hubiese cumplido con la obligación del artículo 3 letra d) de la Ley del Consumidor'.

Como se puede advertir, esta solución jurisprudencial afirma que la utilización de una infraestructura concesionada durante su fase de explotación da lugar a una relación jurídica de naturaleza contractual que une al concesionario y al usuario; contrato que tendría la naturaleza de bilateral y conmutativo, toda vez que el usuario se obliga a pagar una tarifa de circulación a través de la ruta y el concesionario se vincula, a su vez, a consentir el uso por parte de quien haya hecho pago de la tarifa en condiciones de normalidad y seguridad, dando así cumplimiento a la obligación que emana de la regulación propia contrato de concesión de obra pública (art. 23 LCOP) y a las disposiciones de la LPC en materia de seguridad del consumidor (artículos $3^{\circ}$, letra d), y 23 LPC).

\footnotetext{
18 Por ejemplo, Corte de Apelaciones La Serena Rol N 186-2013.

19 Siempre en la sentencia de la Corte de Apelaciones La Serena Rol N 186-2013, sin perjuicio de la jurisprudencia citada más adelante.

20 DIEZ 2007, 86.
} 
Como ya se dijo, esta comprensión del problema ha sido acogida -aunque con vaivenes- por la jurisprudencia de varias Cortes de Apelaciones y, en alguna ocasión, también, por la Corte Suprema.

Los pronunciamientos de las Cortes de Apelaciones generalmente se manifiestan bien sobre la calidad de consumidores y prestadores de servicios de las partes, bien sobre la inaplicabilidad de la excepción del art. $2^{\circ}$ bis LPC que incluye dentro del ámbito de regulación aquellas situaciones que -disciplinadas por leyes especiales, como la LCOP- no cuentan con mecanismos procesales específicos para reclamar la responsabilidad del proveedor.

Así, es posible encontrar ejemplos de este tipo de decisiones en sentencias de las Cortes de Apelaciones de Santiago, San Miguel, Valparaíso y La Serena ${ }^{21}$.

La argumentación de estas sentencias se desenvuelve en el modo que da cuenta la sentencia de la Corte de San Miguel Rol No 8-2020, la cual estableció:

Tercero: Que conforme las alegaciones hechas valer, la doctrina ni la jurisprudencia han resultado pacíficas en torno a la materia y todo se resuelve sobre la base de las interpretaciones que de las normas que rigen el asunto se haga, tanto a nivel doctrinal, como jurisprudencial. Hecha esta salvedad y acerca de los elementos que faltarían para que se configure un acto de consumo, que es lo que cuestiona el recurrente a través de su alegación de incompetencia, a juicio de estos sentenciadores sus argumentaciones resultan erradas. En efecto, el artículo $2^{\circ}$ de la Ley de Protección al Consumidor dispone: "Quedan sujetos a las disposiciones de esta ley: a) Los actos jurídicos que, de conformidad a lo preceptuado en el Código de Comercio u otras disposiciones legales, tengan el carácter de mercantiles para el proveedor y civiles para el consumidor"; y en su artículo $2^{\circ}$ bis, dispone que: "No obstante lo prescrito en el artículo anterior, las normas de esta ley no serán aplicables a las actividades de producción, fabricación, importación, construcción, distribución y comercialización de bienes o de prestación de servicios reguladas por leyes especiales, salvo: c) En lo relativo al derecho del consumidor o usuario para recurrir en forma individual, conforme al procedimiento que esta ley establece, ante el tribunal correspondiente, a fin de ser indemnizado de todo perjuicio originado en el incumplimiento de una obligación contraída por los proveedores, siempre que no existan procedimientos indemnizatorios en dichas leyes especiales".

\footnotetext{
${ }^{21}$ Corte de Apelaciones Valparaíso Rol No324-2012; Corte de Apelaciones San Miguel Rol № 6792013; Corte de Apelaciones Valparaíso Rol No 424-2014; Corte de Apelaciones Valparaíso Rol $N^{\circ}$ 104-2015; Corte de Apelaciones Santiago Rol No 663-2015; Corte de Apelaciones La Serena Rol № 224-2015; Corte de Apelaciones Santiago Rol No 8- 2017; Corte de Apelaciones San Miguel Rol NN 970-2017; Corte de Apelaciones San Miguel Rol № 8-2020, ex mult.
} 
Cuarto: Que delimitado el marco jurídico que rige el asunto, en cuanto a la primera reclamación efectuada por el recurrente en orden a no ser la actividad que desarrolla un acto de comercio, el artículo $3^{\circ}$ en su numeral 20 del Código de Comercio establece que: "Son actos de comercio, ya de parte de ambos contratantes, ya de parte de uno de ellos: 20. Las empresas de construcción de bienes inmuebles por adherencia, como edificios, caminos, puentes, canales, desagües, instalaciones industriales y de otros similares de la misma naturaleza"..

Saldada esta interrogante, queda determinar si la ley de concesiones contempla un procedimiento para la resolución del asunto. [...] En este sentido, el artículo 35 de la Ley de Concesiones simplemente contempla una norma que indica los daños de los que responde el concesionario frente a terceros, mas no contempla un instrumento procedimental para resolver el asunto, de modo que la concurrencia de este punto alegado tampoco resulta demostrada.

Como puede apreciarse, la sentencia recién transcrita, junto con calificar la relación entre concesionario y usuario como una relación de consumo, sostiene que la vía judicial aplicable para la reparación de daños es aquella prevista por la LPC y no el artículo 35 LCOP norma que, según la sentencia, no establecería mecanismo procedimental alguno que permita considerarla dentro de las excepciones del artículo $2^{\circ}$ bis LPC.

Si bien esta tendencia jurisprudencial considera la responsabilidad contractual como una regida por las normas de la LPC y, por ello, sujeta a los procedimientos judiciales de dicha ley, no cabe olvidar que alguna sentencia ha sostenido que la responsabilidad contractual del concesionario es de derecho común. En efecto, la sentencia de la Corte de Apelaciones de Santiago Rol No 8-2017, si bien afirma que la responsabilidad del concesionario es de naturaleza contractual, concluye que ella no debe perseguirse al amparo de la LPC toda vez que concluye que la regulación especial a la que se refiere su art. $2^{\circ}$ bis se encuentra constituida por el artículo 35 LCOP y, por ello, corresponde su conocimiento al juez ordinario.

Considerando $4^{\circ}$ : Sobre el particular se tiene en consideración que la Ley de Concesiones en su artículo 35 regula la materia que sirve de fundamento a la querella infraccional y demanda civil, toda vez que señala que el concesionario responderá de los daños, de cualquier naturaleza, que con motivo de la explotación de la obra se ocasionaren a terceros. Es, precisamente, lo que acontece en este caso, en que un tercero, pues el querellante lo es si se considera que el texto legal regula las relaciones entre el otorgante de la concesión y la concesionaria, reclama la indemnización de los perjuicios sufridos con motivo del hecho que denuncia. Como se trata de una ley especial, queda comprendida entre las excepciones a que se refiere el artículo $2^{\circ}$ bis antes mencionado, por lo que el conflicto planteado no puede ser resuelto al amparo de la norma- 
tiva de la Ley $N^{\circ} 19.496$, debiendo serlo por la vía ordinaria ante el juez naturalmente competente, que lo es el juez de letras en lo civil.

La sentencia, como se ve, hace primar la norma del artículo 35 LCOP por sobre aquella del artículo $2^{\circ}$ bis, letra c) LPC, considerando de esta manera que la responsabilidad contractual del concesionario es una responsabilidad de derecho común.

Como se ha visto hasta el momento, esta corriente jurisprudencial identifica el pago del peaje con la celebración de un contrato entre el usuario y el concesionario, reconociendo generalmente la responsabilidad contractual al amparo de la LPC de este último por los daños sufridos por su 'cliente'. Por ello, la circunstancia de verificarse, o no, un pago por parte del usuario de la obra concesionada reviste -en modo indebido, como se dirá más adelanteuna relevancia fundamental al momento de determinar el régimen jurídico de la responsabilidad del concesionario.

En razón de lo anterior, el hecho que el usuario no pague -o, bien, no pruebe haber pagado- una tarifa por el uso de la infraestructura ha hecho concluir a alguna Corte de Apelaciones que no resulta aplicable el régimen jurídico previsto por la LPC.

De esta forma, la Corte de Apelaciones de Valparaíso, en sentencia Rol No641-2015, sostuvo que:

Séptimo.- Que así las cosas, se hacía indispensable que el demandante acreditara con algún medio de prueba legal la afirmación efectuada en su libelo pretensor en orden a que existía un contrato con la sociedad concesionaria respecto a su circulación en el tramo donde se produjo el accidente. Sin embargo, no rindió probanza alguna para establecer tal circunstancia, ni tampoco es posible presumir tal vínculo de algún antecedente conocido, pues de los elementos del proceso no es posible determinar desde qué lugar venía el vehículo conducido por el actor y consiguientemente si en algún momento pagó una tarifa o peaje a la Sociedad Concesionaria demandada, por el uso de alguna ruta que se une a la Vía Las Palmas y en que por tal motivo podría entenderse que se formó una relación contractual.

Octavo.- Que, por consiguiente, no es posible concluir que el demandante pagó una determinada tarifa o peaje en virtud de la cual se le permitió el acceso a la Ruta en cuestión, vale decir, que celebró un acto jurídico oneroso con la sociedad concesionaria, por lo que no se verifica la condición objetiva contemplada en el artículo $1^{\circ}$ en relación al artículo 2 a) de la Ley $N^{\circ} 19.496$, que permite su aplicación.

En razón de lo anterior, solo corresponde desestimar la responsabilidad infraccional de la demandada y consecuentemente, rechazar la demanda civil interpuesta en su contra. 
Esta sentencia es buena muestra de los problemas de coherencia que presenta considerar que la responsabilidad del concesionario como de tipo contractual. El principal de ellos consiste en que el surgimiento de responsabilidad por los accidentes sufridos por los usuarios de la obra concesionada se hace depender de que estos hayan pagado la tarifa por el uso de la infraestructura, lo que supone condicionar la responsabilidad de origen legal del concesionario al cumplimiento de las obligaciones por parte del usuario. La incoherencia se hace más evidente si se considera que no todos quienes utilizan una infraestructura concesionada tienen el deber de pagar alguna tarifa por el uso de la misma; cuestión que ocurre no solo en aquellas infraestructuras en las cuales el pago del concesionario proviene directamente del concedente a través de los subsidios (como en los hospitales o centros de cumplimiento penitenciario), sino también en aquellas otras en las cuales no todos los usuarios reciben el servicio para el cual fue proyectada la obra, como los peatones que usan las pasarelas en una autopista, o bien, quienes hacen ingreso a un recinto aeroportuario, pero no en calidad de pasajeros. La doctrina jurisprudencial que se viene comentando entregaría una respuesta diferenciada respecto de estos sujetos, cuestión que parece criticable desde el punto de vista de la igualdad de la protección a las víctimas de estos accidentes.

Pese a lo anterior, esta postura jurisprudencial ha sido acogida, aunque aisladamente, por la Corte Suprema la cual, en sentencia Rol N6370-2009, estableció:

Sexto: Que, habiéndose establecido que la relación entre concesionario y usuario es de derecho privado, procede clasificar el contrato existente entre ellos como bilateral, con-sensual, oneroso y conmutativo. Respecto a la denominación jurídica y a las características específicas de este contrato, nos encontramos con que tanto doctrinaria como jurisprudencialmente no hay unanimidad en su clasificación, aunque todos lo consideran una relación regida por el derecho privado ${ }^{22}$.

Como se dijo, esta posición ha sido pocas veces expresada por la Corte Suprema la cual, por el contrario, en su jurisprudencia más reciente sostiene la inexistencia de una relación contractual entre usuario y concesionario calificando como extracontractual la responsabilidad por los accidentes sufridos en vías concesionadas. Junto a este argumento, creo, se puede encontrar una segunda razón, que atiende a las distintas tipologías de concesiones de obras públicas para concluir que esta responsabilidad es extracontractual y que no se sujeta a la Ley del Consumidor.

\footnotetext{
22 Igual decisión se repite en Corte Suprema Rol N²911-2011, en la cual se sostuvo que "el usuario del servicio en su relación con la concesionaria está en una situación contractual, ligado a la concesión por un contrato de derecho privado, en que las prestaciones recíprocas entre los contratantes se constituyen por laprovisión, de un lado, de una ruta o camino con determinadas características cualitativas de rango relativamente superior $y$, de otro, el pago de un valor prefijado por ello".
} 
Esta postura será analizada a continuación.

\subsection{La responsabilidad del concesionario como responsabilidad civil extracontractual}

La mayoría de la doctrina y la jurisprudencia sostienen que la responsabilidad del concesionario por los accidentes sufridos por los usuarios en las obras públicas concesionadas, específicamente en las autopistas, es de naturaleza extracontractual.

En este sentido se pronuncia, por ejemplo, Rufián Lizana quien recuerda que la LCOP engloba el cobro de las tarifas y su sistema de reajuste entre aquellas materias que deben ser regidas "con arreglo a las normas del derecho público" (art. 21 LCOP).

De acuerdo con esta autora, la circunstancia que el cobro de tarifas se deba regir por las normas de derecho público coloca al usuario que debe pagar por la utilización de una obra concesionada en la misma situación de un usuario de un bien nacional de uso público (calidad que, por lo demás, tienen las autopistas concesionadas). La autora reconoce, sin embargo, que "la tarifa constituye la contraprestación del usuario por el uso del servicio"23.

Es en esta dualidad regulatoria donde encuentra origen el problema que ocupa este trabajo: por un lado, la LCOP somete el cobro de las tarifas al derecho público (excluyendo, con ello, el surgimiento de una relación contractual directa entre el concesionario y el usuario de la obra) y, por otro, la difundida (e intuitiva) consideración de que el pago del peaje corresponde a la contraprestación de un servicio que recibe el usuario, en su calidad de cliente del concesionario. Por ello, para esclarecer esta dualidad regulatoria del cobro que realiza el con cesionario de obras públicas, resulta necesario dejar de considerar el peaje como precio de un servicio y, con ello, al usuario como cliente del concesionario. Para ello es posible recurrir, no solo a la jurisprudencia que se reseñará en este apartado si no que, también, al análisis de otros arreglos contractuales en materia de concesiones, que dejan en evidencia que el servicio que el concesionario presta no es retribuido por el usuario por medio de sus pagos, sino que por el Estado.

El argumento central de la tesis que considera la responsabilidad del concesionario como una responsabilidad aquiliana se centra en el contenido de las obligaciones que adquiere el concesionario con el Estado y el estándar de cumplimiento de dichas obligaciones que la LCOP. A este respecto, como veremos a continuación, la jurisprudencia de la Corte Suprema interpreta el artículo 23 LCOP sosteniendo que impone al concesionario el deber de prestar el servicio concesionado en condiciones de normalidad ${ }^{24}$. Si, como consecuencia del incumplimiento de dicho estándar se producen daños a ter-

\footnotetext{
23 RuFián 2018, 157.

24 "El estándar que debe observar el concesionario durante la fase de explotación de la obra es el de normalidad": Corte Suprema Rol N 6229-2010, cons. 17, citando a Barros 2005.
} 
ceros, quien debe responder es el concesionario, de acuerdo con el artículo 35 LCOP. De este modo, cabe concluir, que respecto del usuario, la insatisfacción del estándar de normalidad es una situación de naturaleza extracontractual cuyas consecuencias son puestas ex lege a cargo del concesionario.

De esta manera, la jurisprudencia consolidada en la Corte Suprema considera que el incumplimiento de dicho estándar en la prestación del servicio por parte del concesionario corresponde a una infracción del contrato de concesión, una de cuyas consecuencias consiste en el deber de indemnizar a los terceros que sufran daños derivados de dicha ausencia de normalidad. En este sentido, por ejemplo, en sentencia Rol N²16-2011, la Corte Suprema estableció que:

Vigésimo quinto: Que con arreglo a lo que se ha razonado a lo largo de este fallo, es inequívoco concluir que en la sociedad demandada recaía el deber de seguridad en la explotación y conservación de las rutas concesionadas traducido en la especie en la implementación de una señalización adecuada consideradas las particulares características del tramo en que ocurrió el accidente y su entorno, conclusión a la que en definitiva llega el fallo impugnado, obligación que como se ha visto nace del artículo 23 del D.F.L. 160 en correspondencia con las normas reglamentarias relacionadas, sin que sea óbice para ello la circunstancia que específicamente no se haya considerado en las bases técnicas una señalización en el lugar referido, porque como se ha advertido la obligación legal es permanente y no dice relación con una medida específica de seguridad.

Sin perjuicio de cuanto señalado hasta ahora, cabe considerar un argumento adicional para estimar que la responsabilidad del concesionario es de tipo extracontractual. Dicho argumento dice relación con la naturaleza de la tarifa que debe pagar el usuario. Este razonamiento -que ha sido poco explorado por la Corte Suprema- fue extensamente analizado por un voto disidente de una sentencia de la Corte de Santiago conforme al cual el peaje pagado por el uso de autopistas concesionadas debe ser calificado de tributo.

En la referida sentencia ${ }^{25}$, el voto disidente escrito por el abogado integrante señor Eduardo Morales sostiene que:

En las concesiones, el Estado contrata con un particular la construcción de una obra pública, la que paga con el producido de los peajes. En las concesiones de obra pública hay claramente dos etapas: la de construcción y la de reparación y mantención (explotación), pero en ambas, los servicios se prestan y pagan directamente por el Estado, sea con fondos propios o, como ocurre en la segunda etapa, con la recaudación de los peajes $[\ldots]$.

${ }_{25}$ Corte de Apelaciones Santiago Rol Nº 663-2015. 
Así las cosas es que la sociedad denunciada no puede ser calificada como "proveedor", ya que no presta ningún servicio a los contribuyentes, sino que al Estado concedente, y los usuarios tampoco pagan un "precio o tarifa", sino que pagan peajes, pagan un tributo al único ente que puede establecerlos y cobrarlos, esto es, al Estado26.

El disidente concluye que la relación entre el usuario y el concesionario de una obra concesionada no se debe regir por el derecho del consumo, por no existir ni un proveedor ni un consumidor y que, no habiendo una relación contractual, la responsabilidad por los daños sufridos por este es de naturaleza extracontractual y la competencia para conocer de la relativa causa, del juez ordinario.

Aun sin llegar a calificar el peaje como un tributo, la Corte de Apelaciones de Valdivia había sostenido una conclusión similar ya en 2013. En sentencia Rol No 110-2013, afirmó que:

Considerando $5^{\circ}$ : Entonces, puede concluirse que la tarifa que cobra la sociedad concesionaria, se encuentra regulado (sic) en términos y condiciones que no puede fijarlos ni alterarlos en forma unilateral, por encontrarse sometido a las bases de la licitación, según las cuales se adjudicó la concesión.

Considerando $6^{\circ}$ : En consecuencia, la obligación que impone el artículo 12 de la Ley de Protección del Consumidor al proveedor de un servicio, no resulta aplicable a la sociedad concesionaria de una ruta, como lo es la demandada de autos, al no tener la tarifa un origen convencional que haya sido acordado entre éstos

Considerando $7^{\circ}$ : El peaje o tarifa que paga el usuario de la carretera no transforma en un contrato civil el servicio prestado por la empresa y consecuentemente, si la empresa no cumple con la obligación contenida en el contrato de concesión y provoca perjuicios a terceros, estamos frente a un (sic) responsabilidad de carácter extracontractual, a la que resulta aplicable las normas de los artículos 2314 y siguientes del Código Civil.

También la Corte de Apelaciones de Valparaíso ha seguido este camino argumentativo. En efecto, en sentencia Rol No229-2015, este Tribunal calificó al peaje como un gravamen sosteniendo que:

A mayor abundamiento, así también lo ha entendido mayoritariamente la doctrina al calificar el régimen de responsabilidad civil aplicable en la especie, como extracontractual, teniendo para ello presente entre otros argumentos: a) que la carretera concesionada es un bien nacional de uso público, cuyo ejercicio puede limitarse al cumplimiento de ciertas exigencias o condiciones, como lo es el pago de peaje o tarifa, el que no tiene el carácter de una prestación propia de los contratos onerosos y b)

${ }^{26}$ En contra, RufIÁN 2018, 181, sostiene que los ingresos derivados de la explotación de la concesión son de naturaleza privada y no pueden, por ende, considerarse tributos. 
que dicho peaje o tarifa tampoco puede asimilarse a la contraprestación propia de los contratos onerosos conmutativos, en tanto no existe equivalencia en las prestaciones, si se compara el servicio que la concesionaria pone a disposición del usuario y la tarifa que éste paga para transitar por la ruta, estimándose, en consecuencia, el peaje o tarifa como un gravamen impuesto al usuario de un bien nacional de uso público cuya naturaleza no se ve alterada por ser recaudado por la Concesionaria.

Estas sentencias de agosto y octubre de 2015 recogen la doctrina que venía asentando la Corte Suprema ya desde enero de 2013 y que se consolidó con la sentencia de 23 de junio de 2015, Rol № 27950-2014. En este faIlo, la Corte Suprema, efectúa un extenso análisis de la doctrina que afirma la naturaleza extracontractual de la responsabilidad del concesionario de rutas concesionadas y afirma que:

Octavo: [...] Es necesario reiterar lo que ha señalado esta Corte respecto a la naturaleza de la responsabilidad que podría afectar a una concesionaria ante un accidente ocurrido en una ruta concesionada. Tal como se sostuvo en los autos rol $N^{\circ} 6918-2008$, el estatuto jurídico aplicable a la responsabilidad que atañe a una sociedad concesionaria por los daños ocurridos en una ruta o carretera concesionada se rige por su ley propia y por las de orden extracontractual o de culpa aquiliana.

Para alcanzar esta conclusión, el fallo sostiene:

que quienes siguen la tesis extracontractual [...] parten de la premisa de que el peaje es una contribución de naturaleza tributaria y no un precio a cambio del cual el concesionario pone a disposición de aquél las vías en perfecto estado de seguridad. De esto concluyen que no habiendo relación contractual entre usuario y concesionario, la responsabilidad derivada de los daños causados a los primeros por el mal estado del camino es de carácter extracontractual.

Esta posición jurisprudencial se encuentra suficientemente reflejada también en los más recientes fallos de la Corte Suprema. De esta manera, en la sentencia de 11 de diciembre de 2019, Rol № 16.684-2018 se sostuvo:

Segundo: Que es menester recordar que la responsabilidad del concesionario, en el caso de caminos y autopistas, se funda en la calificación que debe hacerse respecto del estándar de cuidado y, en este sentido, el artículo 23 de la Ley de Concesiones impone el deber de asegurar la continuidad de la prestación del servicio y a facilitarlo en condiciones de absoluta normalidad, suprimiendo las causas que originen molestias, incomodidades, inconvenientes o peligrosidad a los usuarios de las obras. Por otro lado, en términos más amplios, el artículo 62 del Reglamento de Concesiones dispone que: La sociedad concesionaria deber adoptar, durante la concesión, todas las medidas para evitar daños a terceros y al personal que trabaja en la obra. Igualmente deber tomar todas las 
precauciones para evitar daños a la propiedad de terceros y al medio ambiente durante la concesión de la obra.

La jurisprudencia también se ha hecho cargo de descartar el argumento relacionado con la ausencia de un procedimiento especial de reclamación de daños en la LCOP, circunstancia que haría regir la excepción prevista en el art. $2^{\circ}$ bis LPC.

A este respecto, la sentencia de la Corte de Santiago de 30 de junio de 2017, Rol N 8-2017, expresó que:

Sobre el particular se tiene en consideración que la Ley de Concesiones en su artículo 35 regula la materia que sirve de fundamento a la querella infraccional y demanda civil, toda vez que señala que el concesionario responderá de los daños, de cualquier naturaleza, que con motivo de la explotación de la obra se ocasionaren a terceros. Es, precisamente, lo que acontece en este caso, en que un tercero, pues el querellante lo es si se considera que el texto legal regula las relaciones entre el otorgante de la concesión y la concesionaria, reclama la indemnización de los perjuicios sufridos con motivo del hecho que denuncia. Como se trata de una ley especial, queda comprendida entre las excepciones a que se refiere el artículo $2^{\circ}$ bis antes mencionado, por lo que el conflicto planteado no puede ser resuelto al amparo de la normativa de la Ley 19.496, debiendo serlo por la vía ordinaria ante el juez naturalmente competente, que lo es el juez de letras en lo civil [...].

Me parece que el cuadro jurisprudencial está suficientemente delineado y resulta posible sostener que la jurisprudencia de la Corte Suprema, siguiendo alguna doctrina de derecho civil $^{27}$, se inclina por descartar la existencia de una relación contractual entre los concesionarios de autopistas y sus usuarios. De esto se sigue que dichos sujetos no adquieren la calidad de proveedor y consumidor motivo por el cual la LPC no resulta aplicable a los litigios en que se intente determinar la responsabilidad del concesionario.

Por el contrario, esta línea jurisprudencial sostiene que los usuarios de las obras públicas concesionadas tienen, a los efectos del art. 35 LCOP, la calidad de terceros que, si sufren daños, deben ser indemnizados por el concesionario. Dicha indemnización se deberá si la empresa concesionaria no satisface el estándar de normalidad que le impone el art. 23 LCOP, tratándose por ende de una responsabilidad extracontractual por infracción del estándar indicado. En este sentido, la jurisprudencia de la Corte Suprema ha acogido plenamente la tesis formulada por $\mathrm{Diez}^{28}$, conforme con la cual dicho estándar de normalidad exige una especial diligencia al concesionario.

\footnotetext{
27 Véase Rabat 2007 y Zelaya 2011

28 DIEZ 2012.
} 
Para terminar con esta exposición, cabe señalar que la tesis de la naturaleza extracontractual de la responsabilidad del concesionario ha sido acogida, también, por diversas Cortes de Apelaciones ${ }^{29}$.

No obstante la claridad de la posición jurisprudencial resumida en este apartado, ella puede ser perfeccionada toda vez no se hace cargo más que de la responsabilidad del concesionario de autopistas. Según mi opinión, existen razones relacionadas con la naturaleza del contrato de concesión de obras públicas y con la forma en la cual dicho contrato altera la repartición de los riesgos entre el Estado y el concesionario para estimar, con mejores fundamentos, que la responsabilidad del concesionario de obras públicas en general -y no solo la del concesionario de autopistas- es de naturaleza extracontractual.

Dichas razones serán expuestas a continuación.

\section{Argumentos adicionales que refuerzan que la responsabilidad del concesionario de obras públicas frente a terceros durante el período de explotación es de naturaleza extracontractual}

Ya se ha afirmado que la doctrina mayoritaria y la jurisprudencia, tanto de la Corte Suprema como de algunas Cortes de Apelaciones, sostienen que la responsabilidad del concesionario de autopistas por los daños sufridos por los usuarios de las mismas es de naturaleza extracontractual. Para alcanzar esta conclusión, tanto la jurisprudencia como la doctrina se han valido de un argumento que, si bien es correcto, resulta insuficiente: el pago que realiza el usuario de una autopista no corresponde al precio de un contrato de servicios, descartándose con ello la existencia de este tipo de relación jurídica (y, con ello y de paso, la aplicación de la LPC).

Sin embargo, me parece que esta respuesta no considera, al menos, tres situaciones: primero, aquella de los terceros no usuarios de las carreteras concesionadas que sufren accidentes en ellas. Segundo, la situación de los usuarios de infraestructuras concesionadas en las cuales no se debe realizar algún pago. Tercero, la posición del Estado como titular del servicio público prestado por el concesionario. Este último punto será tratado en el apartado siguiente.

Si se piensa bien, no debiera existir razón alguna para distinguir los efectos de un eventual incumplimiento del concesionario del estándar de normalidad en sus obligaciones de servicio (recordemos: de servicio público) según si el usuario de la infraestructura paga, o no, por su uso. ¿Por qué un conductor que hace uso de la autopista se debe encontrar en una condición jurídica distinta de la de un peatón que hace uso de una pasarela sobre la

\footnotetext{
29 Por mencionar solo las sentencias pronunciadas con posterioridad al año 2012: Corte de Apelaciones Santiago Rol N 663-2015, Corte de Apelaciones Santiago Rol N 4968-2016, Corte de Apelaciones Talca Rol No272-2015, Corte de Apelaciones Valdivia Rol N 110-2013; Corte de Apelaciones Valdivia Rol N 179-2015, Corte de Apelaciones Valparaíso Rol N²29-2015.
} 
misma autopista? ¿Por qué un usuario de un hospital público concesionado debiera estar sometido a una prescripción extintiva más breve que la de un pasajero de un aeropuerto? ¿Por qué se debiera presumir la culpa en el incumplimiento para unos (los conductores que pagan por el uso de las autopistas o los pasajeros de un aeropuerto) y no para los otros usuarios en obras públicas concesionadas (el peatón que cruza la pasarela o el familiar del pasajero de un aeropuerto que ingresa al recinto para despedirlo)? Esta última situación es particularmente gráfica: si un pasajero que ingresa al aeropuerto sufre un accidente que afecta también a su acompañante, ambos se encontrarían sometidos a regímenes de responsabilidad distintos: el pasajero podría invocar la LPC y su acompañante debería recurrir al régimen común de responsabilidad aquiliana. Estas disparidades de tratamiento dan buena cuenta de la falta de coherencia de la doctrina que considera esta responsabilidad como de naturaleza contractual.

Creo que todos estos problemas pueden ser superados considerando que la solución planteada por la Corte Suprema no se hace cargo de la responsabilidad del concesionario, en general, sino que solo sirve a explicar la responsabilidad del concesionario de autopistas respecto de los conductores. Y esa explicación atiende a un dato insuficiente, esto es, como ya se dijo, a la naturaleza jurídica de la tarifa de circulación. Solo si se amplía la mirada a todas las situaciones que pueden presentarse en los distintos tipos de concesiones de obras públicas se puede advertir que el único régimen que trata en modo coherente la responsabilidad de los concesionarios es el régimen de responsabilidad aquiliana: solo así se puede establecer un estatuto jurídico único para todas las hipótesis antes mencionadas que otorgue el mismo tratamiento jurídico a personas que detentan igual calidad, esto es, usuarios de obras públicas concesionadas.

La jurisprudencia ha avanzado en este camino, aunque sin llegar a elaborar una solución de aplicación general a todos los tipos de concesiones. De este modo ha tenido oportunidad de resolver casos en que el accidentado era un peatón que hacía uso de una calle de servicio.

La Corte de Apelaciones de Talca, por medio de sentencia del 22 de septiembre de 2010, Rol N820-200830, estableció la responsabilidad extracontractual de los demandados (la concesionaria y el fisco) como consecuencia de la muerte de una menor de edad atropellada mientras atravesaba una calle de servicio emplazada frente a su escuela. La calle de servicio no contaba con las medidas de seguridad adecuadas para proteger eficazmente la vida de sus principales usuarios, esto es, los menores que asistían a dicha escuela.

En esta causa, no se hace cuestión de la naturaleza de la responsabilidad, toda vez que la víctima era un peatón que no había (y no debía haber)

${ }^{30}$ Comentada por Alarcón 2011, aunque con conclusiones sobre la responsabilidad del Estado seriamente debatibles. 
pagado un peaje. Se aplicó un régimen distinto al que podría haberse aplicado en el caso que un conductor sufriera un accidente en el mismo tramo vial.

Por ello cabe preguntarse: ¿acaso el pago del peaje es suficiente justificación para colocar al conductor de un vehículo motorizado en una mejor situación jurídica para demandar la reparación de los daños que sufra como consecuencia de un accidente conforme al estatuto de la responsabilidad contractual? ${ }^{31}$. Esta pregunta debe tener, naturalmente, una respuesta negativa: el pago del peaje no transforma la relación entre el concesionario y el usuario-conductor en un contrato.

Igual situación la hallamos en aquellas infraestructuras concesionadas para cuya utilización el usuario no debe realizar pago alguno. Como ya se dijo, el artículo 11 LCOP permite a la Administración conceder la explotación de infraestructuras cuya construcción o rehabilitación será solventada por el mismo Estado por medio de subsidios, esto es, por medio de pagos periódicos destinados a remunerar la construcción del inmueble y los servicios que el concesionario prestará directamente a la Administración durante el período de explotación. Un ejemplo de este tipo de obras lo encontramos en las cárceles y hospitales públicos concesionados ${ }^{32}$.

Por ello, si un interno de un recinto penitenciario o un paciente de un hospital público concesionado sufre un infortunio (piénsese, por ejemplo, en una intoxicación como consecuencia del mal manejo del servicio de alimentación del recinto por parte del concesionario), no cabe duda alguna que se estará ante un caso de responsabilidad extracontractual, ya que ni el recluso, ni el paciente han debido efectuar pago alguno al concesionario por la utilización de la infraestructura. ¿Se justificaría, entonces, someter a estas víctimas de un daño a un régimen jurídico distinto de aquél que resultaría aplicable al conductor de un vehículo que sufre un accidente en una autopista concesionada por el simple hecho que este ha pagado un peaje? De nuevo, la respuesta solo puede ser negativa, ya que importaría la aplicación de un régimen jurídico desigual y menos ventajoso a unos usuarios respecto de otros, pese a que ambos tienen idéntica calidad como usuarios de obras concesionadas.

Extremando el ejemplo, cabe recordar que en varios países del mundo, algunas obras viales (autopistas, puentes o túneles) son remunerados por el Estado sin recaudación de peajes. Se trata de los denominados 'peajes en la sombra' (shadow tolls), por medio de los cuales el Estado quien paga directamente y con fondos propios el uso que los conductores hacen de infraestructuras concesionadas ${ }^{33}$. Cabe, acá, nuevamente, repetir la pregunta: ¿en una

\footnotetext{
31 Las diferencias de régimen de los dos ámbitos de responsabilidad son de sobra conocidas. Por nombrar dos disparidades favorables a quien invoca el estatuto de la responsabilidad contractual se pueden mencionar la innecesaria prueba de la culpa y un plazo de prescripción extintiva más extenso.

32 Sobre los subsidios en las concesiones de obras públicas, FLORES 2011.

33 Sobre la técnica, puede consultarse MaIRAL 2013 y Yescombe 2007.
} 
autopista concesionada el solo pago del peaje hace que el conductor que sufre un accidente se apropie de un estatuto jurídico distinto?

Estas consideraciones sirven para reforzar las conclusiones ya alcanzadas por la jurisprudencia de la Corte Suprema en los fallos citados en este trabajo: la responsabilidad del concesionario de obras públicas es de naturaleza extracontractual y solo este régimen permite otorgar un tratamiento unitario a todas las hipótesis que pueden presentarse en los distintos tipos de concesiones vigentes en nuestro país.

La razón de cuanto señalado se encuentra en que el contrato de concesión importa, primordialmente, y como ya se dijo, una delegación a una empresa privada de la prestación de un servicio público. La remuneración del contratista-concesionario proviene siempre del Estado, sea que él lo pague directamente (a través de los subsidios), sea que autorice al concesionario a la recolección de pagos por uso, en forma de peajes o derechos. Por eso, en este punto, es relevante cuanto afirman aquellas sentencias que reconocen en el peaje una naturaleza no contractual respecto del usuario. Al considerar la tarifa como un pago realizado al Estado, pero recaudado por el concesionario, se disipa la sombra contractual que oscurece el régimen de responsabilidad por daños sufridos por los terceros. Y no son solo razones dogmáticas las que empujan a concluir que la tarifa recaudada por el concesionario es un pago que se realiza al Estado, sino que las mismas bases de licitación la consideran de tal forma. Dicho de otro modo, el contrato de concesión se remunera, precisamente, por medio de la autorización a cobrar por el uso de la infraestructura; dicho derecho de cobro es otorgado por el Estado al concesionario y corresponde a la prestación del Estado a favor de este y no es el antecedente de una relación de consumo entre el concesionario y el usuario.

En conclusión, el peaje o derecho pagado por el usuario de una obra concesionada no es sino la forma en que el Estado remunera al concesionario; remuneración que se produce a través de la recaudación de este gravamen de parte del público usuario y constituye un derecho emanado del contrato de concesión de obra pública a favor del concesionario y no de un inexistente contrato privado entre concesionario y usuarios.

\section{La posición del Estado: ¿cuándo hay falta de servicio?}

Como ya se indicó, existe una tercera cuestión que debe ser abordada y es aquella de la posición del Estado frente a los daños sufridos por los usuarios durante la etapa de explotación de una concesión.

Si bien la cuestión se encuentra resuelta a nivel legislativo en el art. 35 LCOP, la jurisprudencia ha adoptado soluciones novedosas, que conviene recordar.

La norma indicada establece que es el concesionario quien debe responder de los daños ocasionados durante la explotación de la concesión. Como bien indica Valdivia, "el tipo de negocio que representa la concesión 
lleva consigo un grado importante de autonomía de gestión para el concesionario, lo que se traduce en una dirección y supervisión atenuadas por parte de la autoridad concedente" 34 . De ello se sigue una traslación de riesgos (en este caso, de riesgos de responsabilidad) desde el titular teórico del servicio público al gestor de la actividad, esto es, al concesionario ${ }^{35}$.

La solución que acoge nuestra legislación se encuentra en línea con algunas adoptadas en el extranjero. Así, por ejemplo, en el derecho español, el art. 258, letra e), de la Ley 9/2017, sobre Contratos del Sector Público, prevé como obligación del concesionario la de "indemnizar los daños que se ocasionen a terceros por causa de la ejecución de las obras o de su explotación". Esta norma, por su parte, tiene su antecedente en el artículo 121.2 de la Ley de Expropiación Forzosa (Ley 16/1954) que dispone que "en los servicios públicos concedidos correrá la indemnización a cargo del concesionario, salvo en el caso en que el daño tenga su origen en alguna cláusula impuesta por la Administración al concesionario y que sea de ineludible cumplimiento para éste" ${ }^{36}$. Si se advierte bien, la norma tiene una evidente semejanza con nuestro artículo 35 LCOP.

La jurisprudencia ha aplicado la norma, generalmente, en modo correcto. Así, por ejemplo, la Corte Suprema en sentencia Rol N²16-2011, acogió un recurso de casación en el fondo dirigido por el fisco contra una sentencia que había condenado, en sede de responsabilidad extracontractual, tanto a la concesionaria como al mismo fisco por un accidente ocurrido en la Autopista del Sol (Santiago-San Antonio), consistente en la colisión del vehículo conducido por el actor contra un caballar que se encontraba presente en el calzada.

En la sentencia, la Corte Suprema estimó infringido el artículo 35 LCOP y sostuvo:

Considerando 14: Que son las disposiciones indicadas las que regula (sic) en este caso el sistema de responsabilidad y a la luz de ellas es ineludible concluir que el Fisco de Chile no incurrió en responsabilidad por falta de servicio, puesto que tratándose de los daños ocasionados a terceros con motivo de la explotación de la obra concesionada solo existe responsabilidad estatal cuando los daños sean exclusivamente imputables a medidas impuestas por el Ministerio de Obras Públicas, después de haber sido adjudicado el contrato. Así, en el régimen de concesiones de obras públicas en Chile existe una norma explícita que consiste en que cuando el Estado ha delegado la provisión de servicio de una obra pública fiscal en cuanto a su explotación, ejecución, reparación o mantención en el sector privado, su responsabilidad indemnizatoria solo surge cuando con motivo de su labor de fiscalización impone una medida que es la

\footnotetext{
34 Valdivia 2019, 20. Agradezco al autor por permitirme citar un trabajo aun no publicado.

35 Ibíd., 19. Más en general, sobre los riesgos de la concesión Loo 2014, cap. II; Loo 2016, passim.

36 Sobre el régimen de responsabilidad de los concesionarios en el derecho español, antes de la Ley 9/2017, puede consultarse BOCANEGRA 1994.
} 
causante del daño, en cuyo caso el servicio prestado es deficiente. Debe tenerse presente que el propósito de la Ley de Concesiones de Obras Públicas radica en que el sujeto responsable sea el concesionario. De igual modo surge la responsabilidad del Fisco, por la posible omisión en que pueda incurrir la autoridad competente en la fiscalización y supervigilancia en la prestación del servicio por la concesionaria.

De lo anterior se sigue que:

Considerando $15^{\circ}$ : Los jueces del fondo cometieron error de derecho por errónea interpretación del artículo 35 de la Ley de Concesiones de Obras Públicas por cuanto obviaron que el daño ocurrido a terceros durante la explotación de la obra pública fiscal concesionada no derivó de una medida impuesta por el Ministerio de Obras Públicas, como tampoco de la omisión en la supervigilancia del servicio prestado por la concesionaria, puesto que se dejó establecido como hecho de la causa la presencia periódica del inspector fiscal en la época del accidente. A lo anterior se suma el antecedente fáctico que los cercos de la autopista se encontraban en buen estado, sin advertir deficiencias en los mismos.

Por tal razón, se anuló la sentencia y, en aquella de reemplazo, se exoneró al fisco del pago de indemnización, condenándose únicamente a la concesionaria.

La Corte Suprema ha realizado un singular esfuerzo sistemático en esta materia al decidir una causa derivada de un accidente ocurrido en la Ruta 5 Sur. En la sentencia de 5 de noviembre de 2013, Rol N 4292-2012, se falló una controversia en la que el único demandado era el Fisco, pues el accidente ocurrió en una parte de la ruta (el puente sobre el río Maipo) que, de acuerdo con las condiciones del contrato de concesión, solo debía ser mantenida en el estado en que se encontraba (y no reconstruida o rehabilitada) por la concesionaria. La Corte determinó que el accidente se había producido como consecuencia de las deficiencias preexistentes en la vialidad del puente.

La sentencia estableció que:

En esa línea argumental, la responsabilidad del Fisco de Chile puede apreciarse en al menos tres hipótesis:

A.- Por excepción, cuando con motivo de la ejecución o explotación de la obra fiscal concesionada se ocasionen daños a terceros por medidas exclusivamente impuestas por el Ministerio de Obras Públicas [...].

B.- El Fisco responde por la ausencia de control y fiscalización de los deberes del concesionario [...].

C.- Una tercera hipótesis surge dado que el Puente Maipo es una obra preexistente y que la Sociedad Concesionaria por bases de licitación solo tenía respecto de éste un deber de mantenimiento [...]. 
En otras palabras, el Fisco es responsable de los daños causados por deficiencias viales que derivan de la omisión de esos deberes.

De esta peculiar situación del puente (que no era una obra concesionada, sino que había sido 'incorporada' a la concesión en el estado en que se encontraba al momento de la adjudicación, produciendo un hiato en la continuidad de la autopista concesionada) se sigue una conclusión razonable: la inaplicación del artículo 35 LCOP, en el sentido que el concesionario no es responsable por los accidentes ocurridos en ese sector de la obra, pues no había debido intervenirla.

Entonces, cabe concluir que, en la medida que los daños se originen en la actuación (o falta de ella) del concesionario, la responsabilidad recae exclusivamente en él ${ }^{37}$. Solo de manera excepcional y cuando el hecho sea imputable al Estado, este deberá responder ${ }^{38}$. Esta conclusión es plenamente consistente con el régimen de responsabilidad de la Administración vigente en nuestro ordenamiento, conforme al cual el Estado debe responder de los daños causados por la Administración cuando ella haya actuado con falta de servicio. Por tal motivo, si la actividad específica de explotar una obra pública se encuentra delegada en el concesionario la ley pone a cargo suyo las consecuencias perjudiciales de tal explotación, a menos que dichas consecuencias perjudiciales emanen de una decisión o actuación (erradas) de la autoridad. Ante esta hipótesis, se interrumpe el régimen de responsabilidad del concesionario y se retorna a la regla general, esto es, que la Administración debe responder de sus actuaciones erradas, culposas o tardías.

Las reglas de la LCOP residencian en el concesionario la responsabilidad aquiliana derivada de su conducta y ello se verifica como consecuencia del desplazamiento, de la delegación de la tarea pública a dicho concesionario. Esto, según la doctrina, es consistente con el régimen general de las concesiones conforme con el cual el Estado delega la ejecución de un servicio público en un sujeto privado ${ }^{39}$. Sin embargo, de esto no puede seguirse -como indica el mismo autor ${ }^{40}$ - que el Estado se sitúe como garante de la responsabilidad del concesionario, porque ello importaría una alteración del sistema responsabilidad personal vigente en nuestro derecho y que ha sido bien delineado por la jurisprudencia citada en este apartado. Dicho sistema importa que el Fisco y el concesionario deben responder de sus propias conductas: este, cuando infringe el estándar de cuidado impuesto por la LCOP (dicho estándar es, recordemos, la normalidad de la prestación del servicio público correspondiente) y, aquél, cuando incurre en falta de servicio, que no es otra cosa que el funcionamiento anormal de la Administración Pública.

\footnotetext{
37 Corte Suprema, Rol No 216-2011.

38 Corte Suprema, Rol No 4292-2012.

39 Barros 2005, 530.

40 Ibid., 531.
} 
Esta última consideración, si bien es cierto, permite acercar los regímenes de responsabilidad aplicables al concesionario y al concedente (ambos responden por sus conductas anormales) no puede llevar, sin embargo, a sostener que ambos se encuentren sometidos a un régimen de responsabilidad idénticos, toda vez que la normalidad o anormalidad en el funcionamiento de los servicios se deberá juzgar a la luz de las exigencias propias de cada actividad que, en el caso del concesionario y el concedente, atendida la distinta naturaleza de sus misiones, son distintas.

\section{Conclusiones}

De cuanto referido en esta investigación se pueden alcanzar las siguientes conclusiones.

I. El contrato de concesión de obras públicas permite que el Estado delegue la prestación de un servicio público en un contratista que es remunerado durante la etapa de explotación de la concesión. Esta remuneración puede provenir tanto de la recolección de pagos realizados por los usuarios de la obra (peajes, derechos, tarifas), o bien, directamente del Estado a través de los subsidios.

II. El hecho que el usuario de una obra concesionada deba pagar una tarifa ha provocado que, por un período, la jurisprudencia estimara que los accidentes ocurridos en la obra generaban responsabilidad contractual, toda vez que el pago de dicho peaje fue interpretado como equivalente al pago del precio de un contrato de servicios.

III. Tal posición jurisprudencial fue corregida por la Corte Suprema la cual, acogiendo la opinión de la doctrina mayoritaria, considera que el pago de la tarifa por parte del usuario no equivale a la conclusión de un contrato. Con ello, ha excluido la aplicación de la Ley del Consumidor a los casos de responsabilidad por accidentes viales en rutas concesionadas, haciendo aplicable el régimen de responsabilidad aquiliana de derecho común.

IV. Sin embargo, resulta necesario establecer un régimen general de la responsabilidad del concesionario por los daños sufridos por terceros durante el período de explotación de la concesión que resulte aplicable a todas las obras concesionadas, independiente de su naturaleza. Tal régimen es el de la responsabilidad extracontractual y resultará aplicable a todos los contratos de concesión, cualquiera sea la forma en que se remuneren, con el fin de evitar diferencias de trato jurídico respecto de las víctimas que, en definitiva, tienen siempre la misma calidad: usuarios de una obra concesionada.

V. Finalmente, el Estado puede resultar responsable de los daños sufridos por los usuarios de un servicio concesionado solo cuando ellos se deriven directamente de la conducta de la Administración en las restringidas hipótesis establecidas tanto por el artículo 35 LCOP como por la jurisprudencia de la Corte Suprema esto es, cuando se posible imputar a la Administración falta de servicio. 


\section{Bibliografía citada}

Alarcón Jaña, P. (2011). Solidaridad en el pago de indemnización de perjuicios por responsabilidad del Estado y de sociedad concesionaria en accidente en vía concesionada (autopista). En J. Arancibia Mattar, J. I. Martínez Estay, y A. Romero Seguel (Eds.), Litigación Pública (pp. 323-342). Thomson Reuters.

Arancibia Mattar, J. (2019a). La concesión de bienes nacionales: concepto, objeto, fines y consecuencias prácticas. En J. Arancibia Mattar y P. Ponce Correa (Eds.), El dominio público. Actas de las XV Jornadas de Derecho Administrativo (2018) (pp. 327-375). Tirant lo Blanch.

Arancibia Mattar, J. (2019b). Naturaleza y justicia de los contratos administrativos. Revista de derecho administrativo económico (30), 27-53.

BARRos Bourie, E. (2005). Tratado de responsabilidad extracontractual. Editorial Jurídica de Chile.

Bermúdez Soto, R. (2019). El concepto de servicio público como fundamento para la regulación de actividades económicas [Tesis doctoral. Facultad de derecho PUCV, Valparaíso].

Bocanegra Sierra, R. (1994). La responsabilidad civil de los concesionarios y contratistas de la Administración por daños causados a terceros. Documentación administrativa (237238), 205-238.

Diez Schwerter, J. L. (2007). Reparación y prevención de daños derivados de deficiencias viales en Chile: panorama normativo y jurisprudencial. Revista de derecho Universidad de Concepción, 221-222, 71-98.

Diez Schwerter, J. L. (2012). La responsabilidad civil del concesionario de obras viales y su fundamento en la obligación de seguridad respecto de los usuarios en el derecho chileno. Revista de derecho de la Pontificia Universidad Católica de Valparaíso, 38, 121-156.

FLORES Rivas, J. C. (2011). Concepto y naturaleza de la subvención en el derecho chileno. El caso de la concesión de obra pública. Revista de Derecho de la Pontificia Universidad Católica de Valparaíso, 37, 329-367.

Loo GutiérRez, M. (2014). I principi di sussidiarietà e solidarietà nel partenariato pubblico-privato contrattuale. Aracne.

Loo GutiérRez, M. (2016). La distribución de los riesgos en el contrato de concesión de obra pública. En J. Bermúdez Soto (Ed.), Perspectivas para la modernización del derecho de la contratación administrativa. Actas de las XI Jornadas de derecho administrativo (2014) (pp. 191-206). Ediciones Universitarias de Valparaíso.

Loo GutiérReZ, M. (2018). Posicionamiento dogmático de la actividad contractual de la Administración del Estado. Revista de Derecho de la Pontificia Universidad Católica de Valparaíso, 50, 129-155.

Loo GutiérRez, M. (2019a). El desafío de las concesiones de obra pública: ¿qué (y qué no) concesionar? Revista de derecho (Valdivia), 32(2), 185-206.

Loo GutiérRez, M. (2019b). Las concesiones de obra pública: ¿qué son y por qué se utilizan en Chile? Revista Derecho del Estado, 44, 327-359.

MaIraL, H. A. (2013). Los riesgos en la financiación privada de proyectos públicos. Revista de derecho administrativo Pontificia Universidad Católica del Perú (13), 201-222.

Moraga Klenner, C. (2019). Contratación administrativa (2a ed.). LegalPublishing.

Rabat Celis, F. (2007). Responsabilidad civil de las sociedades concesionarias de obras públicas fiscales respecto del usuario de las mismas. En Estudios jurídicos en homenaje a los profesores Fernando Fueyo Laneri, Avelino León Hurtado, Francisco Merino Scheihing, Fer nando Mujica Bezanilla, Hugo Rosende Subiabre (pp. 279-298). Universidad del Desarrollo.

Rufián LizANA, D. (2018). Manual de concesiones de obras públicas (2a ed.). Andros Impresores.

Valdivia Olivares, J. M. (2018). Manual de derecho administrativo. Tirant lo Blanch.

Valdivia Olivares, J. M. (2019). Responsabilidad del Estado por el hecho de sus contratantes en el derecho chileno (Inédito).

Viñuela Hojas, M. (2001). La responsabilidad por falta de servicio en el contexto del régimen de concesiones viales vigente en Chile. lus publicum, 7, 33-55. 
Viñuela Hojas, M. (2003). La concesión de obra pública en Chile: ¿Privatización de la responsabilidad del Estado en la empresa concesionaria? En J. Baraona González (Ed.) Cuadernos de extensión jurídica Universidad de Los Andes, 7, 109-135. Universidad de Los Andes.

Yescombe, E. R. (2007). Public-private partnerships: principles of policy and finance. Butterworth - Heinemann.

Zelaya Etchegaray, P. (8 de noviembre de 2011). La responsabilidad extracontractual de las autopistas concesionadas frente a los daños de los usuarios. El Mercurio Legal.

\section{Normativa citada}

Decreto Supremo No 900 [Ministerio de Obras Públicas]. Fija el texto refundido, coordinado y sistematizado del DFL MOP N 164, de 1991, Ley de concesiones de obras públicas (LCOP). 31 de octubre de 1996.

Decreto Supremo No 956 [Ministerio de Obras Públicas]. Reglamento DFL MOP Nº 164 de 1991. 6 de octubre de 1997.

Ley N 19.496 de 1997. Establece normas sobre protección de los Derechos de los Consumidores. 7 de marzo de 1997. D.O. N 35.710.

\section{Jurisprudencia citada}

Corte Suprema. Primera Sala. Rol No 6370-2009, 7 de agosto de 2011.

Corte Suprema. Tercera Sala. Rol No 6229-2010, 4 de diciembre de 2012.

Corte Suprema. Primera Sala. Rol No 2911-2011, 16 de mayo de 2012.

Corte Suprema. Tercera Sala. Rol N²16-2011, 30 de enero de 2013.

Corte Suprema. Tercera Sala. Rol No 4292-2012, 5 de noviembre de 2013.

Corte Suprema. Cuarta Sala. Rol No 5678-2012, 29 de abril de 2013.

Corte Suprema. Primera Sala. Rol N²7950-2014, 23 de junio de 2015.

Corte Suprema. Primera Sala. Rol No 10.649-2015, 1 de junio de 2016.

Corte Suprema. Primera Sala. Rol No 16.684-2018, 11 de diciembre de 2019.

Corte de Apelaciones de Talca. Sala N/A. Rol No 820-2008, 22 de septiembre de 2010.

Corte de Apelaciones de Valparaíso. Tercera Sala. Rol 324-2012, 20 de agosto de 2012.

Corte de Apelaciones de San Miguel. Sexta Sala. Rol No 679-2013, 4 de julio de 2013.

Corte de Apelaciones de Valdivia. Segunda Sala. Rol No110-2013, 3 de septiembre de 2013.

Corte de Apelaciones de Valparaíso. Segunda Sala. Rol No 424-2014, 2 de octubre de 2014.

Corte de Apelaciones de La Serena. Sala extraordinaria. Rol No 186-2013, 12 de noviembre de 2014.

Corte de Apelaciones de Valparaíso. Segunda Sala. Rol No 104-2015, 4 de mayo de 2015.

Corte de Apelaciones de Valparaíso. Tercera Sala. Rol N²29-2015, 24 de agosto de 2015.

Corte de Apelaciones de Santiago. Séptima Sala. Rol No 663-2015, 28 de octubre de 2015.

Corte de Apelaciones de Talca. Segunda Sala. Rol No 272-2015, 6 de noviembre de 2015.

Corte de Apelaciones de Valdivia. Primera Sala. Rol No 179-2015, 19 de noviembre de 2015.

Corte de Apelaciones de Valparaíso. Primera Sala. Rol N641-2015, 19 de enero de 2016.

Corte de Apelaciones de La Serena. Primera Sala. Rol N²24-2015, 7 de junio de 2016.

Corte de Apelaciones de Santiago. Novena Sala. Rol N4968-2016, 14 de octubre de 2016.

Corte de Apelaciones de Santiago. Primera Sala. Rol N 8-2017, 30 de junio de 2017.

Corte de Apelaciones de San Miguel. Sala N/A. Rol No970-2017, 17 de noviembre de 2017.

Corte de Apelaciones de San Miguel. Tercera Sala. Rol N 8-2020, 7 de abril de 2020. 